\title{
Cell Wall Ultrastructure of Strains of Haemophilus ducreyi and Haemophilus piscium
}

\author{
M. KILIAN AND J. THEILADE \\ Departments of Microbiology and Electron Microscopy, Royal Dental College, Aarhus, Denmark
}

\begin{abstract}
The Gram reactions and cell wall topographies of six strains of Haemophilus piscium, including the type strain, and four strains assigned to Haemophilus ducreyi were studied to elucidate the taxonomic position of the two species. All strains were predominantly gram negative when stained by the Gram method but showed differences in staining between individual cells. The six strains of $H$. piscium and one strain of $H$. ducreyi exhibited a cell wall of the gram-negative type, whereas the remaining three strains of $H$. ducreyi exhibited a cell wall structure typical of gram-positive microorganisms. The study thus confirms the classification of $H$. piscium as a gram-negative bacterium but indicates that the name $H$. ducreyi has been used for different groups of bacteria. Only one of the strains of $H$. ducreyi investigated can legitimately be assigned to the genus Haemophilus, and more information is required to settle the taxonomic position of the remaining three strains.
\end{abstract}

The name Coccobacillus ducreyi was proposed by Neveu-Lemaire (16) for the organism first isolated by Ducrey (7) from soft chancres. Because of special nutritional requirements, Ducrey's bacillus is now classified as a species of Haemophilus. The organism is known for the difficulties encountered in its cultivation, and the information on its physiological and biochemical characteristics is consequently sparse. A type strain of the species has never been designated, and due to conflicting data on its biochemical properties, growth factor requirements, and even Gram reaction, there seems to be some uncertainty about the true nature of Ducrey's bacillus. Nicolau and Banciu (17) found that, after a number of subcultures, their strains became gram positive although they were markedly gram negative on primary isolation. de Assis (6) found that the Gram reaction was dependent on the method used for fixation of the preparation prior to staining, whereas Reymann (Ph.D. thesis, Copenhagen, 1951) found all his newly isolated strains to be consistently gram negative. Deacon et al. (4) reported on a gram-positive phase of the Ducrey bacillus, but later realized that they inadvertently had been working with strains of Corynebacterium acnes (5).

$H$. piscium, originally described by Snieszko et al. (25), is the only Haemophilus species that requires diphosphothiamine but neither hemin nor nicotinamide adenine dinucleotide (NAD) for growth $(10,11)$. Recent studies (M. Kilian, manuscript submitted for publication) have demonstrated several other significant differ- ences between $H$. piscium and the type species $H$. influenzae, which call the taxonomic position of $H$. piscium into question.

In view of the uncertain classification of $H$. ducreyi and $H$. piscium and in the interest of a greater taxonomic understanding of them, we chose to study the ultrastructure of some representative strains of the two species in an electron microscope with special reference to their cell wall topography.

\section{MATERIALS AND METHODS}

Bacterial strains. The following strains were studied: $H$. ducreyi CIP 542; H. ducreyi 129 (Reymann, Ph.D. thesis); H. ducreyi IX (Reymann, Ph.D. thesis); $H$. ducreyi X (Reymann, Ph.D. thesis); $H$. piscium ATCC 10801 (type strain) (25); $H$. piscium ATCC 14360 (25); $H$. piscium ATCC 14361 (25); $H$. piscium ATCC $14362(25) ; H$. piscium ATCC 14363 (25); $H$. piscium ATCC 15711 (25) (CIP, Collection l'Institut Pasteur, Paris; ATCC, American Type Culture Collection, Rockville, Md.).

Propagation of strains. All strains were cultured on chocolate agar (10\% heated, defibrinated horse blood in blood agar base [Difco]) incubated for 2 days in Baird-Tatlock jars filled with air plus $10 \% \mathrm{CO}_{2}$. The strains of $H$. ducreyi were incubated at $37 \mathrm{C}$ and the strains of $H$. piscium were incubated at $22 \mathrm{C}$.

Cell morphology and staining. A saline suspension of a colony from a 48-h agar culture was examined directly by phase-contrast microscopy, and a heat-fixed smear was stained by Hucker's modification of the Gram staining procedure (12).

Electron microscopy. Prior to fixation, a layer of $1.5 \%$ agar (45 C) in Veronal acetate buffer ( $\mathrm{pH} 6.1$ ) was poured onto the agar plate cultures and allowed to solidify. Small blocks containing the bacterial 
colonies were cut out and prefixed at room temperature in $3 \%$ glutaraldehyde in Veronal acetate buffer (pH 6.1) for $1 \mathrm{~h}$ and subsequently postfixed overnight in $1 \%$ osmium tetroxide in the same buffer to which $1 / 10$ volume of a yeast extract-acetate-peptone medium was added (22). The specimens were then block-stained in $2 \%$ buffered uranyl acetate, dehydrated in alcohol, and finally embedded in Epon. Thin sections were cut through the colonies perpendicular to the original agar surface. The sections were poststained with uranyl magnesium acetate (8) and lead citrate (21) and examined in a Philips EM 200 electron microscope at $60 \mathrm{kV}$.

\section{RESULTS}

H. ducreyi. Cells of the strains 129, IX, and $\mathrm{X}$ were seen as coccobacilli or short slender rods. As shown by Gram staining, they were predominantly gram negative but were interspersed with varying numbers of cells that partly resisted decolorization with ethanol. Strain CIP 542 produced irregular slender rods often arranged in long chains. They were all gram negative.

From examination of thin sections of cells of the four different strains of $H$. ducreyi in the electron microscope, it was evident that strains 129 , IX, and X possessed the same characters, whereas the ultrastructure of cells of $H$. ducreyi CIP 542 was different. Consequently, it will be described separately.

Thin sections of cells of strains 129, IX, and X (Fig. 1 and 2) showed short rods approximately 0.7 by $1.5 \mu \mathrm{m}$ in size (Fig. 2). Many cells had transverse septa indicative of incomplete divisions. At higher magnification (Fig. 1), it was evident that the cells were surrounded by a rather homogeneous cell wall approximately 10 to $15 \mathrm{~nm}$ thick. It appeared to be of medium electron density although the inner and outer outlines were more electron dense than the intermediate region. Externally a flocculent layer about $5 \mathrm{~nm}$ wide was separated from the cell wall by a less dense space also about $5 \mathrm{~nm}$ wide. The cytoplasmic membrane was found in close apposition to the interior of the cell wall and, where transverse septa were present, the cytoplasmic membrane closely followed the intrusion of cell wall material. The cytoplasm was rather electron dense, and generally no distinct nuclear regions were evident. Mesosomes were quite frequently observed, particularly in regions with incomplete septa.

Thin sections of cells of strain CIP 542 showed short rods approximately 0.6 by 1.5 to 0.6 by $2 \mu \mathrm{m}$ in size (Fig. 3 ). At higher magnification the cells were observed to be surrounded by a cell wall approximately $10 \mathrm{~nm}$ in width (Fig. 4). The cell wall consisted of two structural components-an outer membrane of unit membrane type (occasionally with a very undulated appearance) and a thin, rather poorly defined layer of medium electron density situated in the interspace between the outer membrane and the cytoplasmic membrane. In the cell cytoplasm, ribosomes were located mainly peripherally, whereas rather large nuclear regions were evident more centrally.

H. piscium. Cells of the six strains of $H$. piscium were generally small rods of varying length, but occasional filaments were also present. The cells were predominantly gram negative after staining, but a few interspersed cells were not totally decolorized.

The ultrastructures of the six strains were similar to that of $H$. ducreyi CIP 542. All strains appeared as short rods with a cell wall consisting of an outer more or less wavy membrane, and a thin intermediate layer of medium electron density in close apposition to the inner leaflet of the outer membrane (Fig. 5). One of the strains (ATCC 14361) had an extra flocculent layer external to the outer membrane (Fig. 6 ), and this layer often appeared to be detached from the outer membrane of the cell wall. In the cytoplasm, ribosomes were situated mainly peripherally; the nuclear regions as a rule were more centrally situated in the cells.

Fig. 1. Thin section of $H$. ducreyi 129, illustrating a short rod in incomplete division. The cell is surrounded by a rather homogeneous cell wall of medium electron density, although the inner and outer outlines are somewhat more electron dense (arrows). External to the cell wall is a flocculent layer $(F L)$. The cytoplasmic membrane $(C M)$ is located immediately inside the cell wall and follows the intrusion of the cell wall material of the developing septum. $\times 95,000$.

FIG. 2. Thin section of $H$. ducreyi 129 displaying short rods, many of which contain transverse septa. $\times 14,000$.

FIG. 3. Thin section of $H$. ducreyi CIP 542 showing rods of varying length. The tendency to form chains is also illustrated. $\times 14,000$.

FIG. 4. Thin section of $H$. ducreyi CIP 542. The cell is surrounded by a cell wall comprising a triple-layered outer membrane $(O M)$ and a thin intermediate layer (IL) of medium electron density interposed between the outer membrane and the cytoplasmic membrane $(C M)$ of the cell. The cytoplasm contains ribosomes rather evenly distributed in a less dense matrix except for the centrally located nuclear region (NR). 

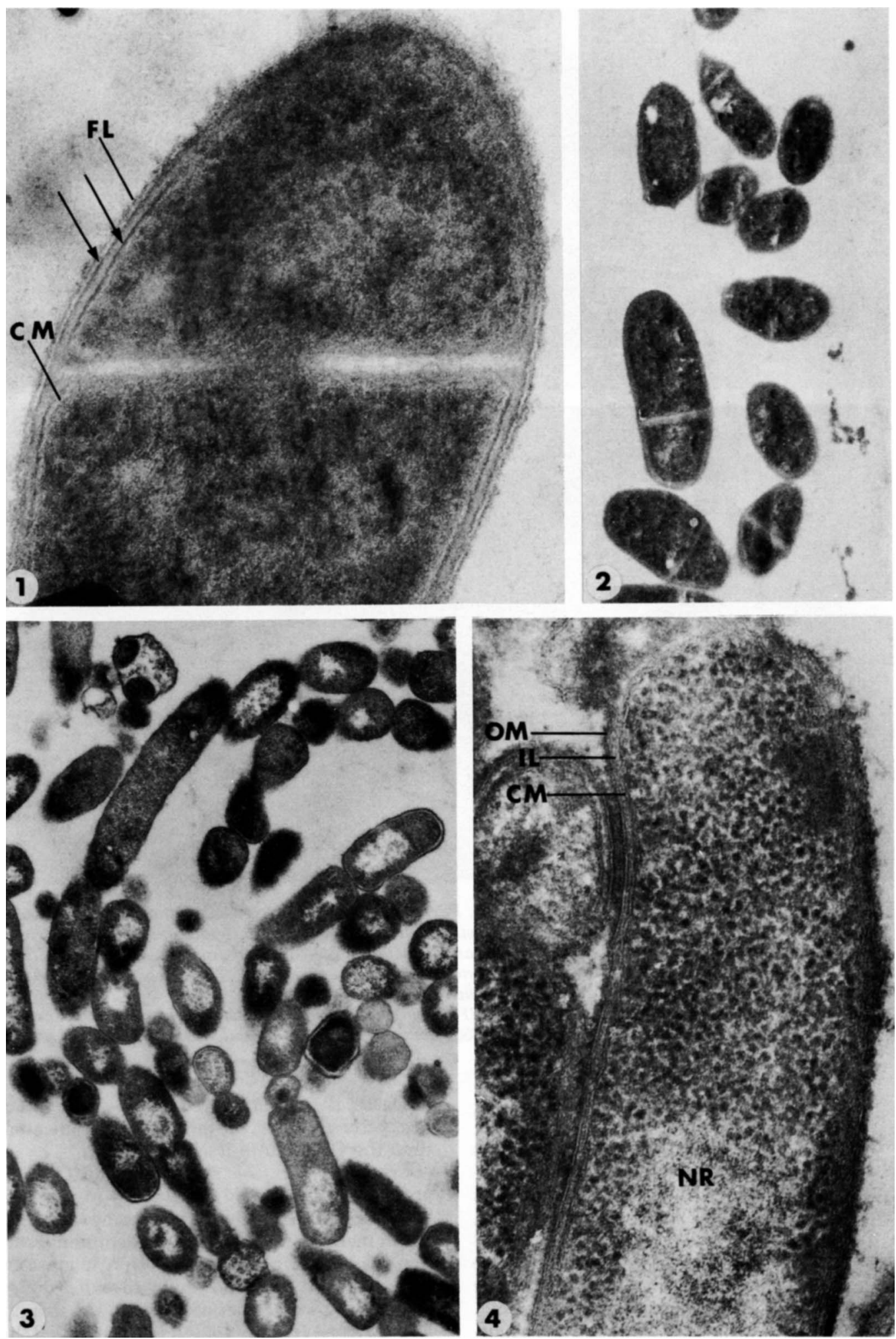

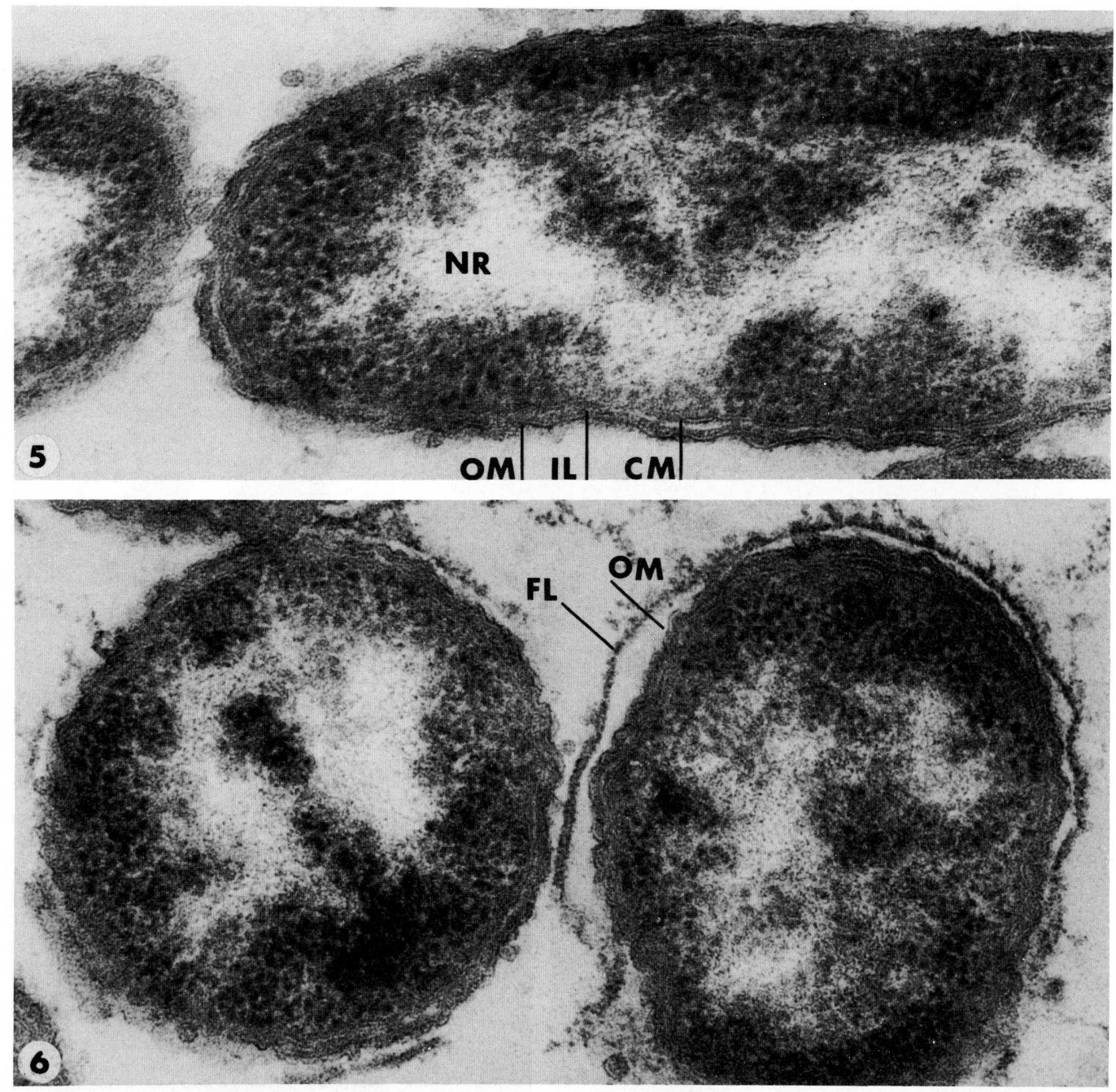

FIG. 5. Thin section of H. piscium ATCC 10801. Part of a short rod is seen surrounded by a cell wall comprising a triple-layered outer membrane $(O M)$ with an undulated appearance and small blebs. In close apposition to the inner leaflet of the outer membrane, a somewhat ill-defined intermediate layer (IL) is interposed between this outer membrane and the cytoplasmic membrane $(C M)$. The ribosomes are peripherally located as they are surrounding the central nuclear region $(N R) . \times 95,000$.

FIG. 6. Thin section of H. piscium ATCC 14361. Two cross-sectioned cells present an ultrastructure similar to that shown in Fig. 5 for strain ATCC 10801, but in addition a flocculent layer (FL) is observed external to the outer membrane $(O M) . \times 95,000$.

\section{DISCUSSION}

The Gram reaction divides bacteria at a high level of taxonomic significance. The composition of the cell wall, which determines the Gram reaction of a bacterium, is dependent, however, on the environment in which the organism is growing $(3,15,24)$, and uncertainty about the Gram reaction may sometimes arise, especially when the bacteria are grown under suboptimal conditions. It is recognized that, in such doubt- ful cases, the pattern of cell wall ultrastructure is a better guide for the purpose of classification than the Gram stain itself $(9,14)$.

Practically all the strains included in the present study showed differences in staining between individual cells when stained with the Gram method, although the predominant reaction was gram negative. Electron microscope studies of the cells, however, revealed differences in cell wall structure between the strains. All strains of $H$. piscium studied, including the 
type strain, had a cell wall structure of the gram-negative type (9). This was also true for one of the $H$. ducreyi strains (CIP 542), whereas the remaining three strains (129, IX and X) exhibited a cell wall structure typical of grampositive microorganisms (9).

The three strains designated $H$. ducreyi and with cell walls of the gram-positive type were isolated approximately 25 years ago from soft chancres by Reymann and were part of a strain collection described in a series of publications (18-20; Reyman, Ph.D. thesis). In agreement with several other authors $(1,2,23)$, Reymann described his strains as requiring a thermostable serum factor and a thermolabile factor, bound to erythrocytes, for growth, but neither hemin (X-factor) nor NAD (V-factor) (Reymann, Ph.D. thesis). Strain CIP 542, with a gram-negative cell wall type, does require hemin but not NAD for growth (Kilian, submitted for publication) in accordance with the findings of Lwoff and Pirosky (13) and the information now given in Bergey's Manual (27) for $H$. ducreyi.

Several authors have noted the mixed microflora of soft chancres $(5,26)$. The present study indicates that the name $H$. ducreyi has been used for different groups of poorly growing bacteria which may be isolated from this infectious disease. This finding probably accounts for the conflicting information on the properties of $H$. ducreyi. On the basis of cell wall structure and growth requirements, only one of the strains (CIP 542) designated $H$. ducreyi can legitimately be assigned to the genus Haemophilus. The taxonomic position of the three gram-positive strains cannot be settled before additional information on various properties is obtained; which of the two different groups of organisms is the Ducrey bacillus, and thus the causative agent of chancroid, is an open question. Only the strain with the gram-negative cell wall type showed the typical strepto-bacillary morphology usually ascribed to $H$. ducreyi $(3,23$, 26), but Reymann (Ph.D. thesis) was able to produce typical chancroids by inoculation of some of his strains in two volunteers. If the specific name $H$. ducreyi is to be conserved, it would be logical, however, to use it for the gram-negative and hemin-dependent organism.

In spite of inconclusive results obtained by the Gram method, the fine structure of the cell wall of $H$. piscium confirms its classification as a gram-negative bacterium. However, there is but small justification for the retention of this species in the genus Haemophilus, as several data indicate. Such data are for example the lack of requirement for hemin or NAD for growth $(10,11)$, the low growth optimum temperature (25), and in particular the failure to reduce nitrate, as well as the relatively high content of guanine and cytosine $(55.1 \mathrm{~mol} \%)$ in the deoxyribonucleic acid (Kilian, submitted for publication). Consequently, the taxonomic position of $H$. piscium should be reconsidered.

\section{ACKNOWLEDGMENTS}

The valuable criticism and suggestions during the preparation of the manuscript by $A$. Birch-Andersen, Department of Biophysics, Statens Seruminstitut, Copenhagen, Denmark, are gratefully acknowledged. This investigation was supported in part by grant 512-4064 from the Danish State Medical Research Council.

\section{REPRINT REQUESTS}

Address reprint requests to: Dr. M. Kilian, Department of Microbiology, The Royal Dental College, 8000 Aarhus, Vennelyst Blvd., Aarhus, Denmark.

\section{LITERATURE CITED}

1. Ajello, G. W., W. E. Deacon, L. Paul, and K. W. Walls. 1956. Nutritional studies of a virulent strain of Haemophilus ducreyi. J. Bacteriol. 72:802-808.

2. Beeson, P. B. 1946. Studies on chancroid. IV. The Ducrey bacillus: growth requirements and inhibition by antibiotic agents. Proc. Soc. Exp. Biol. Med. 61:8185.

3. Cripps, R. E., and E. Work. 1967. The accumulation of extracellular macromolecules by Staphylococcus aureus grown in the presence of sodium chloride and glucose. J. Gen. Microbiol. 49:127-137.

4. Deacon, W. E., D. C. Albritton, W. F. Edmundson, and S. Olansky. 1954. Study of Ducrey's Bacillus and recognition of a gram-positive smooth phase. Proc. Soc. Exp. Biol. Med. 86:261-264.

5. Deacon, W. E., D. C. Albritton, S. Olansky, and W. Kaplan. 1956. V.D.R.L. chancroid studies. I. A simple procedure for the isolation and identification of Hemophilus ducreyi. J. Invest. Dermatol. 26:399406.

6. de Assis, A. 1926. Sur la biologie du bacille de Ducrey. C. R. Séances Soc. Biol. 95:1008-1009.

7. Ducrey, A. 1889. Experimentelle Untersuchungen über den Ansteckungsstoff des weichen Schankers und über die Bubonen. Monatsschr. Prakt. Dermat. 9:387-405.

8. Frasca, J. M., and V. R. Parks. 1965. A routine technique for double-staining ultrathin sections using uranyl and lead salts. J. Cell Biol. 25:157-161.

9. Glauert, A. M., and M. J. Thornley. 1969. The topography of the bacterial cell wall. Annu. Rev. Microbiol. 23:159-198.

10. Griffin, P. J. 1951. Cocarboxylase and adenosine triphosphate as growth factors for Hemophilus piscium. Arch. Biochem. 30:100-102.

11. Griffin, P. J. 1952. Further studies on the nutrition of Hemophilus piscium. Yale J. Biol. Med. 24:411-418.

12. Hucker, G. J., and H. J. Conn. 1923. Methods of Gram staining. N.Y. Agric. Exp. Stn. Tech. Bull. no. 93, p. 129.

13. Lwoff, A., and I. Pirosky. 1937. Determination du facteur de croissance pour Haemophilus ducreyi. C.R. Seance Soc. Biol. 124:1169-1171.

14. Murray, R. G. E. 1962. Fine structure and taxonomy of bacteria, p. 119-144. In G. G. Ainsworth and P. H. A. Sneath (ed.), Microbial classification. XII Symp. Soc. Gen. Microbiol. University Press, Cambridge.

15. Neidhardt, F. C. 1963. Effects of environment on the composition of bacterial cells. Annu. Rev. Microbiol. 
$17: 61-86$.

16. Neveu-Lemaire, M. 1921. Précis de la parasitologie humaine, 5th ed. J. Lemaire, Paris.

17. Nicolau, S., and A. Banciu. 1926. Recherces biologiques sur le streptobacille de Ducrey. C. R. Seance Soc. Biol. 95:409-411.

18. Reymann, F. 1949. Sensitivity of Hemophilus ducreyi to penicillin, streptomycin and sulfathiazole. Acta $\mathrm{Pa}$ thol. Microbiol. Scand. 26:309-318.

19. Reymann, F. 1949. An investigation of the biochemical reactions of Hemophilus ducreyi. Acta Pathol. Microbiol. Scand. 26:345-353.

20. Reymann, F. 1950. Type differentiation of Haemophilus ducreyi. Acta Pathol. Microbiol. Scand. 27:364-377.

21. Reynolds, E. S. 1963. The use of lead citrate at high pH as an electron-opaque stain in electron microscopy. J. Cell Biol. 17:208-212.

22. Ryter, A., and E. Kellenberger. 1958. Etu ${ }^{-}$a au microscope électronique de plasmas contenant de l'acide déoxyribonucléique. $Z$. Naturforsch. 13b:597-605.

23. Sanderson, E. S. 1940. Laboratory aspects of chancroid, granuloma inguinale and lymphogranuloma venereum. Am. J. Public Health. 30:683-686.

24. Shockman, G. D. 1965. Symposium on the fine structure and replication of bacteria and their parts. IV. Unbalanced cell wall synthesis: autolysis and cell-wall thickening. Bacteriol. Rev. 29:345-358.

25. Snieszko, S. F., P. J. Griffin, and S. B. Friddle. 1950. A new bacterium (Hemophilus piscium) from ulcer disease of trout. J. Bacteriol. 59:699-710.

26. Unna, P. G. 1892. Der Streptobacillus des weichen Schankers. Monatsschr. Prak. Dermat. 14:485-490.

27. Zinnemann, K., and E. L. Biberstein. 1974. Genus Haemophilus Winslow, Broadhurst, Buchanan, Krumwiede, Rogers and Smith 1917, 561, p. 364-368. In R. E. Buchanan and N. E. Gibbons (ed.), Bergey's manual of determinative bacteriology, 8th ed. The Williams \& Wilkins Co., Baltimore. 